\title{
Management of viral hepatitis: Clinical and public health perspectives - A Consensus Statement
}

\author{
M Sherman MB BCh PhD FRCPC, CASL Hepatitis Consensus Group
}

$\mathrm{T}$ he Canadian Liver Foundation convened a two-day conference in September 1996, at which experts from across Canada were invited to discuss various aspects of viral hepatitis and to issue guidelines to assist practitioners in caring for patients with these diseases. The proceedings of this conference were transcribed and submitted to all participants for approval before being submitted for publication. The views expressed in this article represent the consensus opinion of the group. Where there was significant difference of opinion this is explicitly stated, and opposing points of view are given.

\section{THERAPY OF CHRONIC HEPATITIS B - STANDARD INDICATIONS}

The standard indications for treatment of hepatitis $B$ virus (HBV) infection have not changed since the publication of consensus guidelines three years ago (1). The only licensed drug for hepatitis B is interferon-alpha. Contraindications to interferon therapy have also not changed since the last consensus conference. These include hepatic decompensation, granulocyte count less than $1000 \times 10^{9} / \mathrm{L}$, platelet count less than $80,000 \times 10^{9} / \mathrm{L}$, major psychosis and autoimmune disease.

\section{CASL Hepatitis Consensus Group participants}

Canadian Association for Study of the Liver: Dr Paul Adams, Dr Vincent G Bain, Dr William Depew, Dr Victor Feinman, Dr Cameron Ghent, Dr Jenny Heathcote, Dr Mang Ma, Dr Sam Lee, Dr Pierre Paré, Dr Eve Roberts, Dr Richard Schreiber, Dr Averell Sherker, Dr Morris Sherman, Dr Urs Steinbrecher, Dr Bernard Willems, Dr CN Williams

Blood Borne Pathogens Division of the Laboratory Centre for Disease Control (LCDC):

Dr P Gully

\section{Canadian Red Cross:}

Dr B Larke

Canadian Liver Foundation:

Mr R McClory, Ms B Potkonjak

Observer from the Krever Commission: $\mathrm{P}$ Chan PhD

Correspondence and reprints: Dr M Sherman, Division of Gastroenterology, Toronto General Hospital, 223-200 Elizabeth Street, Toronto, Ontario M5G 2C4. Telephone 416-340-4756, fax 416-591-2107

Received for publication Jume 10, 1997. Accepted June 11, 1997 
RECOMMENDATION: Hepatitis B early antigen ( $\mathrm{HBeAg}$ )-positive hepatitis $B$ carriers who have alanine aminotransferase (ALT) levels greater than twice the upper limit of normal for more than four months should be treated with interferon-alpha at a dose of 27 to $35 \mathrm{mU}$ weekly for four months. This can be given in divided doses three times a week or daily.

Treatment success is defined as normalization of liver enzymes, seroconversion from $\mathrm{HBeAg}$-positive to anti-HBe (production of antibodies to the e antigen) and clearance of HBV DNA. Seroconversion may be heralded by a self-limited increase in aminotransferases. This flare needs to be distinguished from a relapse. Seroconversion from $\mathrm{HBeAg}$ to anti-HBe may occur only some weeks after completion of treatment. Successful treatment of chronic hepatitis B infection in suitable patients has been shown to enhance survival (2).

HBV DNA testing is not widely available. However, the presence of replicating virus can be inferred from finding high levels of $\mathrm{HBeAg}$ in serum (more than $90 \%$ of $\mathrm{HBeAg}$ positive subjects will have detectable circulating $\mathrm{HBV}$ DNA) and from staining of hepatitis $B$ core antigen ( $\mathrm{HBcAg}$ ) in hepatocyte nuclei on biopsy.

\section{FACTORS AFFECTING RESPONSE TO INTERFERON}

When HBeAg-positive patients in whom the ALT is more than twice the upper limit of normal are treated, a response is seen in $40 \%$ to $50 \%$. The likelihood of response is affected by several factors. High titres of HBV DNA are associated with a poor response. The presence of cirrhosis also decreases the likelihood of response. However, neither of these factors on its own predicts success or failure of treatment with sufficient accuracy to be used to select patients for treatment.

RECOMMENDATION: Patients with liver enzymes less than twice the upper limit of normal respond poorly to interferon-alpha and should not be treated.

\section{PREDNISONE PRETREATMENT}

Prednisone pretreatment is intended to enhance the response to interferon, particularly in patients with normal or near normal ALT. Controlled trials have demonstrated that there is a small additional benefit from prednisone pretreatment $(3,4)$. However, occasional deaths have been reported due to a severe flare of active hepatitis.

RECOMMENDATION: Pretreatment with prednisone should be avoided.
CIRRHOSIS WITH HEPATIC DECOMPENSATION

Use of low dose interferon in patients with hepatic decompensation has been reported (5). Patients with Child's class $C$ cirrhosis should not be treated with interferon under any circumstance. Patients with lesser degrees of hepatic decompensation (Child's class A and B) may be treated with interferon in an escalating dose, starting at $0.5 \times 10^{6} \mathrm{mU}$ three times a week and increasing to a maximum of $3 \mathrm{mU}$ three times a week. Use of interferon in these circumstances is associated with a high rate of complications, including lifethreatening infection and hepatic failure. This use of interferon has to be considered experimental. Some of these patients with hepatic decompensation may also be suitable for treatment with lamivudine, which at present is available only on a compassionate use basis.

RECOMMENDATION: Hepatitis B carriers with hepatic decompensation should be referred to expert centres for management. Liver transplantation may be required.

\section{ANTI-HBe-POSITIVE HBV CARRIERS WITH REPLICATING VIRUS}

A subset of anti-HBe-positive patients remain HBV DNApositive with persistently elevated ALT (6). This form of hepatitis $B$ may be associated with a more aggressive disease course, with rapid progression to cirrhosis and liver failure. The response rate to interferon therapy in this group is initially good, but the relapse rate is high (about 90\%) $(7,8)$. These patients may also be more suitable for lamivudine or famciclovir treatment (see below).

RECOMMENDATION: Anti-HBe-positive hepatitis B carriers with elevated ALT and positive HBV DNA should only be treated with interferon in the setting of experimental studies.

\section{CHRONIC HEPATITIS B IN CHILDREN}

Most infants and young children infected with hepatitis $B$ have normal aminotransferases and are not candidates for therapy. Children who are $\mathrm{HBe} \mathrm{Ag}$-positive with persistently elevated ALT levels for at least four to six months can be considered for treatment. However, there are only a limited number of randomized controlled trials of interferon use in children. In these, the doses ranged from 3 to $9 \mathrm{mU} / \mathrm{m}^{2}$ thrice weekly for 16 to 24 weeks. The response rates ranged from $20 \%$ to $50 \%(9,10)$. Interferon is not yet licensed for use in children with chronic hepatitis $B$.

RECOMMENDATION: Children with chronic hepatitis B should be referred to expert centres for assessment and possible treatment. 


\section{HEPATITIS B-INDUCED \\ GLOMERULONEPHRITIS}

There is only one randomized controlled trial of interferon therapy for hepatitis B-induced glomerulonephritis. To summarize the results of this and other nonrandomized studies, resolution occurred in nearly $100 \%$ of membranous glomerulonephritis, but patients with membranoproliferative glomerulonephritis responded poorly $(11,12)$. Clearance of $\mathrm{HBeAg}$ occurs in about the same proportion of patients as with standard indications.

RECOMMENDATION: The indications for interferon therapy in patients with hepatitis B-induced membranoproliferative glomerulonephritis are the same as for patients without glomerulonephritis. However, in membranous glomerulonephritis kidney disease is an indication for interferon therapy.

\section{HEPATITIS D}

The only well conducted randomized controlled trial (13) showed that a dose of $9 \mathrm{mU}$ three times a week for one year induced virological response, which was sustained for six months after completion of therapy in only $21 \%$ of cases. However, $36 \%$ of patients had a sustained biochemical response (normal ALT). There are no long term data to indicate whether interferon therapy alters mortality or morbidity. This is a very expensive form of therapy (about $\operatorname{CDN} \$ 15,000$ for the entire course) with uncertain benefit and it remains experimental.

RECOMMENDATION: Patients with active hepatitis $D$ should be treated in expert centres.

\section{COMBINED HBV AND HIV INFECTION}

For most patients coinfected with HIV and HBV, HIV is more likely to limit their life span than HBV. HIV-positive patients do not respond well to interferon (14). Therefore, because hepatitis $B$ uncommonly causes increased morbidity, interferon therapy is not recommended. This may change because therapy improves the prognosis of HIV infection. Some of these patients will be treated with lamivudine for HIV. Lamivudine will also suppress HBV replication and can clear HBV DNA from blood in some patients.

RECOMMENDATION: Patients with combined HBV and HIV infections rarely need interferon treatment for HBV infection.

\section{COMBINED INFECTION WITH HBV AND HEPATITIS C VIRUS (HCV)}

The treatment of infection with both $\mathrm{HBV}$ and $\mathrm{HCV}$ is complex and requires sophisticated laboratory facilities. Generally, patients with combined infections will have one infection dominant and then the other dormant. Thus, the patient may have either HBV DNA or HCV RNA in serum, but seldom both (15). The diagnosis of which infection is dominant depends on which nucleic acid is present in serum. The dominant infection is then treated as usual. However, interpretation of treatment outcome is also complicated, ideally also requiring measurement of nucleic acid in serum to ensure that eradication has occurred.

RECOMMENDATION: Patients with combined HBV and HCV infections should be treated in expert centres.

\section{TREATMENT OF RECURRENT HEPATITIS B AFTER LIVER TRANSPLANTATION}

Policies for undertaking liver transplantation in hepatitis B carriers have not been standardized across Canada. Patients with actively replicating hepatitis B will almost invariably develop reinfection of the allograft. In patients with nonreplicating infection (HBV DNA-negative) HBV will recur in about $50 \%$ of cases. Several agents have been demonstrated to be partially effective in preventing reinfection, including high doses of hepatitis B immunoglobulin, lamivudine or famciclovir. There are no comparative studies to assess which of these is most effective. All are associated with the emergence of resistant strains of virus. Some centres will transplant hepatitis $B$ carriers under cover of hepatitis B immunoglobulin prophylaxis or will use nucleoside analogues in experimental protocols.

\section{FAILURE OF INTERFERON THERAPY IN HEPATITIS B}

Patients who have undergone a full course of interferon therapy but have failed to normalize ALT or lose $\mathrm{HBeAg}$ are nonresponders. Retreatment of such patients is usually futile except in certain circumstances, such as if the HBV DNA levels fall spontaneously.

RECOMMENDATION: Retreatment of initial treatment failures with interferon is not recommended. Patients should be referred to an expert centre for consideration of other potential options for treatment.

\section{RELAPSE AFTER TREATMENT}

A small number of patients who initially respond to interferon may relapse some months to years later. (Elevation of ALT immediately after therapy is not considered a relapse, but rather treatment failure.) The definition of relapse requires that after completion of therapy the patient has a pro- 
TABLE 1

Estimated prevalence of chronic hepatitis B infection in Canada*

\begin{tabular}{lrcr}
\hline Country of origin & $\begin{array}{c}\text { Population } \\
\text { in Canada }\end{array}$ & $\begin{array}{c}\text { Estimated } \\
\text { prevalence (\%) }\end{array}$ & \multicolumn{1}{c}{ Total } \\
\hline $\begin{array}{l}\text { Low risk immigrants and } \\
\quad \text { those born in Canada }\end{array}$ & $27 \times 10^{6}$ & 0.56 & 151,200 \\
China & 360,315 & 7 & 25,222 \\
Italy & 705,590 & 3 & 21,288 \\
South Asia & 266,800 & 7 & 18,676 \\
Aboriginals & 746,410 & 2 & 14,928 \\
Africa & 174,790 & 7 & 12,235 \\
Portugal & 199,595 & 3 & 5988 \\
Philippines & 93,280 & 5 & 4664 \\
Greece & 143,780 & 3 & 4313 \\
Vietnam & 53,015 & 7 & 3711 \\
Middle East & 101,665 & 3 & 3050 \\
Korea & 26,855 & 7 & 1880 \\
South America & 80,715 & 2 & 1614 \\
Total & & & 268,769 \\
\hline
\end{tabular}

*Statistics Canada databases provide information about the number of immigrants from different parts of the world. The prevalence of chronic hepatitis $B$ in these populations in Canada is derived from the known prevalence in the native country, with an arbitrary adjustment for a fall in prevalence in the second and subsequent generations

longed period of HBV DNA negativity, with normal ALT, and seroconversion to an anti-HBe-positive state. Patients who relapse after therapy usually respond to a second course of treatment.

RECOMMENDATION: $\mathrm{HBe} A g$-positive HBV carriers who relapse after treatment can be retreated.

\section{NUCLEOSIDE ANALOGUES}

Two nucleoside analogues that have been used to treat hepatitis $B$ have been mentioned previously. Lamivudine is an analogue of cytidine, and famciclovir is an analogue of guanine. Additional agents are being tested. These drugs are not yet licensed for use in hepatitis B. Nonetheless, initial studies have shown that both famciclovir and lamivudine will inhibit hepatitis $B$ replication and often result in clearance of HBV DNA from serum $(16,17)$. There are drawbacks to the use of these agents. Virological and clinical relapse are frequent after treatment is stopped. Drug resistance has been described, but it is rare except in liver transplantation recipients. It is likely that one or more of these agents will become part of the armamentarium of drugs used against hepatitis B, but the way in which these drugs will best be used (alone or in combination, simultaneously or sequentially, etc) has still to be determined.

RECOMMENDATION: Nucleoside analogues remain experimental and should be used only in a trial or on a compassionate basis in selected cases in expert centres.

\section{USE OF HBV DNA TESTING}

HBV DNA testing is not widely available. The consensus group considered whether testing for HBV DNA was an essential part of the management of patients with chronic hepatitis $\mathrm{B}$. In $\mathrm{HBeAg}$-positive patients with elevated liver enzymes, HBV DNA testing is probably not necessary. Almost all such patients will be HBV DNA-positive and meet the criteria for initiating treatment. Furthermore, when assessing response after treatment, normal ALT and seroconversion to anti-HBe are almost always associated with negative HBV DNA (by branched DNA assay). Testing with polymerase chain reaction (PCR) shows that HBV DNA remains positive in many $\mathrm{HBe} \mathrm{Ag}$-positive patients with elevated liver enzymes. However, the clinical significance of this finding is unknown. HBV DNA testing is required in patients who are anti-HBe-positive with persistently elevated liver enzymes. Such patients may harbour actively replicating HBV and may be candidates for treatment. HBV DNA testing may also be required after transplantation and in other clinical situations. Because these situations are uncommon it is unnecessary that HBV DNA assays be widely available.

If the HBV DNA test is not available, other indicators of high level hepatitis $B$ replication include the finding of abundant immunohistochemical staining for $\mathrm{HBcAg}$ in the nuclei of hepatocytes on biopsy or a quantitative estimate of $\mathrm{HBe} \mathrm{Ag}$ in serum.

RECOMMENDATION: HBV DNA testing is advisable, but not essential, to manage $\mathrm{HBe} A g$-positive patients with interferon. HBV DNA testing is essential if any other subgroup of hepatitis B carrier is being considered for treatment.

\section{HEPATITIS B VACCINATION}

Newborns who are infected with HBV have a greater than $90 \%$ chance of becoming chronic carriers. In adults the rate of chronicity after infection is controversial. Older literature suggests that about $5 \%$ to $10 \%$ of HBV-infected adults become carriers. Newer literature suggests that the figure may be lower than that, perhaps as low as less than $1 \%(18,19)$. The corollary is that the majority of carriers worldwide probably come from the pool of infected infants and children.

Acute hepatitis B in Canada is largely a disease of young adults, most often resulting from sexual and injection drug use-related transmission. The extent to which notified cases reflect the real rate of infection is unknown. However, because pediatric infection is rarely symptomatic, the rate of infection in this age group is vastly underestimated.

The major morbidity and mortality from hepatitis $B$ is seen in chronic carriers. Up to $25 \%$ of men infected in childhood can be expected to die from hepatitis B-related complications. Acute hepatitis B, in contrast, rarely causes death.

The current policy of hepatitis $B$ vaccination in most 
provinces in Canada is to provide universal vaccination for school-going children in the preteenage years. In addition, there is universal screening of pregnant women and vaccination of newborn babies of infected mothers with both hepatitis B immunoglobulin and the hepatitis $B$ vaccine. Vaccination is also recommended for specified high risk groups. The maternal screening program and the school age vaccination programs are very successful. There are no data on the efficacy of the program to vaccinate high risk groups. For the most part this requires recognition of risk by family practitioners. There is evidence from the early studies of maternal HBV screening that recognition of risks is poor. The advantages of this vaccination strategy are that there is an immediate impact in preventing disease in adults and that there is good compliance in the schools. However, the affect of this strategy on eradication of the chronic carrier state is uncertain.

The ideal vaccination policy is to screen pregnant women, provide hepatitis $B$ immunoglobulin to their offspring and vaccinate all newborns, as well as to institute a catch-up program for the rest of the population below about age 35 to 40 years. This strategy is supported by the Canadian Paediatric Society and has been instituted in countries where hepatitis B is highly prevalent, such as Taiwan. In Canada, only New Brunswick, Prince Edward Island and the Northwest Territories have introduced universal neonatal vaccination in addition to universal preadolescent vaccination.

Chronic hepatitis B in Canada is largely a disease of immigrants (Table 1). Spread of disease in this population is likely to be similar to that in their native countries, ie, both vertical and horizontal. This was demonstrated in a similar population in the United States (20). The current strategy will prevent most vertical transmission. The crucial issue is whether horizontal transmission in childhood is a significant factor in the spread of hepatitis B in Canada. There are no data on this subject. The consensus group felt that it was imperative that Canadian data be obtained to allow appropriate decision making. The committee believes that despite the lack of data on the prevalence of horizontal transmission in Canada, it is likely an important mode of spread of this disease.

RECOMMENDATION: The most appropriate vaccination strategy for Canada is universal vaccination of all neonates, combined with screening of all pregnant women. Newborn babies of infected mothers should be given hepatitis $\mathrm{B}$ immunoglobulin in addition to the vaccine. A catch-up program should be instituted for all children and young adults who have not yet been vaccinated.

\section{TREATMENT OF ACUTE HEPATITIS C}

Acute hepatitis $C$ is usually diagnosed only following transfusion and in the health care worker who suffers an accidental exposure to hepatitis $\mathrm{C}$. In community-acquired hepatitis $\mathrm{C}$ and in infection associated with injection drug use, the initial infection is usually asymptomatic, and therefore treatment is usually not possible. Interferon in doses ranging from 3 to $10 \mathrm{mU}$ thrice weekly for three to six months has been used $(21,23)$.

RECOMMENDATION: Patients with acute hepatitis C should be treated with interferon at a dose of at least $3 \mathrm{mU}$ three times a week for three to six months.

Treated patients are more likely to have normal ALT levels and negative HCV RNA levels six months after treatment than untreated patients. However, the long term outcome of such treatment is unknown.

Health Canada has recently issued guidelines about the management of health care workers exposed to needlestick injuries (24). The committee considered this problem and recommends that in addition to these guidelines, PCR-based assays be used to test health care workers with needlestick injury from an $\mathrm{HCV}$-positive source. If PCR is not available, branched DNA HCV RNA or third-generation ELISA should be used. HCV RNA may become positive as early as two weeks after infection, well before the anti-HCV assay becomes positive. There are, however, no data to indicate that the timing of initiation of therapy has any effect on the outcome of infection. The following recommendation is based on expert opinion rather than on information in the medical literature.

RECOMMENDATION: Health care workers subjected to needlestick or equivalent exposure should be monitored by the most sensitive test available. Treatment should be started at the first diagnosis of infection.

\section{HEPATITIS C INFECTION IN CHILDREN}

Hepatitis $C$ occurs with high prevalence in children who received multiple blood transfusions before testing for hepatitis $\mathrm{C}$ was introduced. Perinatal infection of children from an infected mother occurs in about $5 \%$ of cases (25). The rate at which the initial infection becomes chronic in these children is unknown. However, the disease in children appears to be mild.

There are two trials of interferon therapy in children $(26,27)$. Both showed good results, but utilized doses higher than those used in adults. Interferon is not licensed for use in children (younger than 18 years), and it is recommended that children not be treated except in the setting of controlled trials. Young children treated with interferon suffer anorexia, weight loss and growth retardation. There is no urgency to treat children, given that the disease is mild and that better treatment may be developed.

RECOMMENDATION: Chronic hepatitis $\mathrm{C}$ in childhood should not be treated except in controlled trials. 
Infected teenagers, however, need to be counselled about the risks of alcohol in the presence of hepatitis $C$, of sexual transmission to others (see below), of acquiring sexually transmitted hepatitis B and of injection drug use.

\section{SELECTION OF PATIENTS FOR TREATMENT FOR CHRONIC HEPATITIS C}

Because therapy with interferon is effective in only a small proportion of patients, it is important to select patients who are most likely to respond to treatment. There are a number of factors that influence the response to interferon; these have been identified retrospectively in various studies of interferon treatment. None has been validated prospectively. For multivariate analysis, the statistical technique used in most of these studies required a correction factor to account for the number of variables studied. Once more than three variables are being studied, it becomes difficult to obtain significance unless the sample size is very large. It is not clear that such correction factors were used in these studies. Failure to use appropriate correction factors will result in overestimation of the likelihood of a significant difference being present, ie, a type 1 error.

\section{ALT LEVELS}

The prime indication for interferon treatment in chronic hepatitis $\mathrm{C}$ is ALT elevation to more than 1.5 times the upper limit of normal for more than four to six months. In subjects with normal ALT levels, interferon treatment often fails to clear HCV RNA $(28,29)$.

RECOMMENDATION: Patients with chronic hepatitis $C$ and normal ALT should not be treated.

\section{HCV RNA LEVELS}

It has also been shown that the response rate to interferon is inversely proportional to the HCV RNA concentration (30-33). Unfortunately HCV RNA testing is not widely available and it is very expensive. There is currently insufficient evidence to allow a given HCV RN A concentration to be used as a criterion for excluding patients from therapy.

RECOMMENDATION: HCV RNA testing is not essential before undertaking treatment in patients with the standard indications.

\section{HCV GENOTYPES}

Classification of hepatitis $\mathrm{C}$ subspecies is based entirely on comparisons of nucleotide sequences. There are at least six different HCV genotypes, and some types have subtypes. Thus, there are types 1 to 6 and subtypes labelled 1a, 1b, 2a, $2 b$, etc (34). Types and subtypes may be identified by amplifying sequences from the 5' noncoding region using typespecific primers or by amplifying sequences from the coding region. There are also type-specific probes, directed at the NS-5 region and the 5' noncoding region. Alternatively there are serological assays based on genotype-specific peptides corresponding to the NS4 and core regions. The biological relevance of the existence of subspecies is unknown. Type $1 \mathrm{a}$ and $1 \mathrm{~b}$ account for more than $60 \%$ of all infections in North America, with types $2 \mathrm{a}$ and 2b, and types 3 and 4 accounting for the rest. Except in Quebec, type 5 is rarely found in North America. Type 4 is common in central Africa and the Middle East, but is rare in Europe. Type 5 is common in South Africa, and type 6 is most prevalent in Hong Kong.

Most studies suggest that infection with type 1 is more aggressive, responds less well to interferon and recurs more rapidly after orthotopic liver transplantation. Patients with type $1 \mathrm{~b}$ infection tend to be older and to have acquired their infection from transfusion rather than injection drug use. Response rates with genotype 1 have been documented to fall between $9 \%$ and $40 \%$ (most often closer to $9 \%$ than $40 \%$ ) $(31,32,35,36)$, whereas response rates in patients with genotypes 2 and 3 have been reported to be as high as $70 \%$ to $90 \%$ in some studies. However, at this stage, genotype alone cannot be used to determine whether to place a patient on treatment. Genotyping is also difficult to obtain.

Hepatitis $\mathrm{C}$ quasispecies are variant genomes of the same genotype, arising within a single patient, derived from the original infecting virus. Quasispecies diversity may increase with time and may contribute to interferon resistance.

Genotyping has predictive value with respect to the outcome of interferon therapy but does not provide sufficient discrimination to determine suitability for treatment.

RECOMMENDATION: HCV genotyping is not required for usual clinical practice.

\section{CIRRHOSIS}

Patients with cirrhosis respond to interferon therapy less well than patients without cirrhosis. However, like all the other predictive factors, cirrhosis alone is insufficient to exclude a patient from treatment. Although other factors, such as older age and longer duration of infection, correlate with poorer response, they do not provide sufficient discrimination to be used alone to decide whom to treat. However, clinical experience has shown that patients with several adverse factors are extremely unlikely to respond to treatment. Thus, in assessing such patients the possible effect of cirrhosis on response rate should be considered in conjunction with other factors, such as age and, if known, HCV RNA concentration and genotype.

RECOMMENDATION: Treatment should not be denied on the basis of cirrhosis alone, but careful consideration should be given to the likelihood of benefit. Patients with hepatic decompensation should not be treated with interferon. 


\section{DOSE AND DURATION OF TREATMENT}

The optimal duration of treatment was considered by the consensus group. The previous consensus document indicated that treatment should be for six months. Subsequent randomized controlled trials (37-39) and a meta-analysis (40) have indicated that the response rate is increased with one year of therapy. However, even with one year of therapy the expected response rate is no more than about $30 \%$.

RECOMMENDATION: Patients with chronic hepatitis $C$ should be treated for one year at a dose of $3 \mathrm{mU}$ thrice weekly.

A minority opinion in the consensus group suggested that some patients, particularly those in a category with a high likelihood of response (young, active disease, no fibrosis, low HCV RNA levels and favourable genotype), could be given six months of therapy, and if a relapse occurred, they could then be retreated for a further 12 months. If this strategy were applied to all hepatitis C-treated individuals, it would be more expensive than simply treating for one year. However, if applied to good risk individuals, it may be a more cost-effective strategy. This needs to be confirmed by clinical studies.

Patients on interferon should have ALT monitored early during treatment. There are several studies showing that the best indicator of sustained long term response is early normalization of ALT (within two to three months).

RECOMMENDATION: If the ALT has not fallen into the normal range after two or three months of treatment, sustained response is unlikely and treatment should be stopped.

Increasing the dose of interferon if the ALT level fails to normalize does not result in long term remission and should be avoided (41). None of these patients will be long term responders. In some patients, even though the ALT has normalized the HCV RNA may still be present in serum. These patients will also fail to be long term responders. Thus, to assess treatment response adequately at two months, HCV RNA testing should be done. Similarly, if breakthrough occurs while on treatment, therapy should be stopped. These patients will also fail to be long term responders.

In assessing whether a patient is a good candidate for interferon therapy, it is important to attempt to assess the likelihood of long term benefit. Thus, elderly patients and patients with intercurrent diseases may not benefit from interferon therapy, even if long term remission is obtained. Chronic hepatitis $C$ has a natural history that may exceed 20 years. Although it may be difficult to pinpoint the time of infection, if the patient's life expectancy is reduced because of age or illness, interferon should not be used. This is par- ticularly true if there is little evidence of chronic liver disease. Conversely, if there is substantial chronic liver disease or cirrhosis in the elderly, it is highly debatable whether even successful treatment of such patients will add to longevity. In addition, elderly patients are more prone to symptomatic side effects, which may limit treatment.

\section{SEXUAL TRANSMISSION OF HEPATITIS C}

Hepatitis $C$ is not considered a sexually transmitted disease, although sexual transmission can occur. This form of transmission is, at best, very inefficient. Hepatitis C RNA has been detected in body fluids, including sperm, saliva, menstrual blood and breast milk in some studies, whereas others have failed to find the virus in these fluids $(42-47)$. In heterosexual partners of infected patients, hepatitis $C$ prevalence ranges from $0 \%$ to $10 \%(48,49)$. A single study from Japan suggested that the prevalence in long term partners was $27 \%$ (50). Once other risk factors, apart from being the sexual partner of an infected individual, are considered, the prevalence of hepatitis $C$ in sexual partners drops to $0 \%$ to $4 \%(49,51)$.

Data from homosexual males are controversial. Most studies indicate a prevalence between $1 \%$ and $3 \%$. In HIVpositive homosexual men there is a similar wide variation in reported prevalence. There appears to be increasing prevalence with increasing number of sexual partners (51-53). This may mean that there is an increased risk of sexual transmission under these circumstances, but it may also indicate that sexual activity is a surrogate marker for other high risk activities, such as injection drug use.

RECOMMENDATION: Sexual partners should be informed by the infected person. Testing should be offered to the sexual partner. Pretest counselling should be given. Patients and their partners should be given full and accurate information about the risks of sexual transmission.

In short term sexual relationships condom use is advised, primarily to protect against other sexually transmitted diseases. This will certainly protect against hepatitis $\mathrm{C}$ as well. In long term relationships there is no recommendation for or against condom use. However, if a couple has been together for some years and transmission has not yet occurred, it is extremely unlikely that transmission will occur. Some common sense precautions should be applied. These include avoiding unprotected sex during menstruation and if there is a genital lesion, such as herpes, and avoiding sexual activity involving trauma (eg, anal intercourse).

Data on the safety of breast-feeding are incomplete. There is no evidence that the disease is spread by breastfeeding, but HCV RNA has been found in breast milk.

RECOMMENDATION: There is no specific recommendation for or against breast-feeding. 


\section{POPULATION SCREENING FOR VIRAL HEPATITIS}

The consensus group considered whether it was appropriate to embark on large scale population screening for hepatitis $B$ and hepatitis $\mathrm{C}$. These are both common diseases with significant mortality and morbidity. Population screening for hepatitis $B$ would afford the opportunity to offer vaccination to family and sexual contacts. An additional benefit would be the identification of patients suitable for treatment. There is evidence that such treatment decreases the incidence of complications such as cirrhosis and hepatocellular carcinoma (HCC) and increases survival (2). Screening should be offered to all members of high risk groups. It is likely that such screening will identify only a fraction of those who are carriers (perhaps 50\%). Thus, additional programs will have to be developed to identify carriers who do not fall into the traditional risk groups.

The consensus group did not feel that widespread population screening for hepatitis $C$ was appropriate. At best, $30 \%$ of those treated will respond to interferon. Furthermore, there is no long term follow-up to prove that responders derive long term benefit from treatment. There is no vaccination that can be offered. Infected individuals could be offered counselling, particularly about alcohol use, but there was a concern that the anxiety provoked by the knowledge of being infected may make widespread screening counter-productive.

This is not meant to discourage hepatitis $\mathrm{C}$ testing where appropriate, nor to discourage appropriate history taking to identify circumstances that predispose an individual to hepatitis $\mathrm{C}$. However, the committee felt that in the absence of identified risk factors or identified liver disease, screening was not appropriate.

RECOMMENDATION: Widespread screening of populations known to be at risk for hepatitis $B$ should be promoted. Screening for hepatitis B in low risk populations is also recommended. Widespread screening for hepatitis $\mathrm{C}$ is not recommended.

\section{SCREENING FOR HCC}

HCC is a well known complication of HBV infection. Although all HBV carriers are at risk for HCC, the risk is highest in those with childhood-acquired disease. In Canada this is largely an immigrant population. HBV carriers who acquired the disease as adults, al though still at increased risk of developing HCC, do not carry as high a level of risk.

Screening for HCC in patients with chronic hepatitis B is standard practice in some communities. In addition, patients with hepatitis $\mathrm{C}$ are also being screened for $\mathrm{HCC}$. There is no evidence that screening is beneficial in reducing mortality from HCC in these populations. Evidence from uncontrolled studies is controversial. There are two large North American studies of screening; one suggested that screening is very effective at finding curable tumours, and the other suggested that it is not $(54,55)$.
There are several reasons why screening might not be effective. The sensitivity of the screening tests (usually regular estimation of alpha-fetoprotein levels and/or ultrasonography) is not high ( $\pm 50 \%$ and $\pm 70 \%$, respectively). Patients with cirrhosis, who are at the highest risk, are those who may be least able to survive a partial hepatectomy. Orthotopic liver transplantation may be effective therapy, but it is limited to patients with unresectable HCC in chronic hepatitis C. In hepatitis B patients, recurrence of hepatitis B posttransplantation is frequent, and transplantation is seldom an option. (This may change with the advent of nucleoside analogues to treat post-transplantation hepatitis B.) The only other therapy that is potentially curative is ethanol injection. However, there are no controlled trials using this treatment modality.

Despite the lack of demonstrated efficacy of screening for HCC, screening is widely carried out. It seems clear that the public would prefer the medical profession to err on the side of caution in this case and to provide screening. Thus, it would probably not be effective to attempt to deny screening. However, if screening is undertaken, several factors should be considered in deciding whom to screen. In some populations the likelihood of benefit from screening is very small, eg, the risk of HCC in noncirrhotic patients with chronic hepatitis C HCC is very low. In contrast, hepatitis B-related HCC is accompanied by cirrhosis in only about $60 \%$ of cases. The incidence of HCC in female hepatitis B carriers is about six to eight times lower than in men, whereas in hepatitis $C$ the incidence of HCC is not related to sex. In hepatitis B, HCC is rare before age 30 and is uncommon in patients who are $\mathrm{HBe} \mathrm{Ag}$-positive. Hepatitis B carriers with decompensated liver disease should not be screened because no treatment can be offered, whereas in chronic hepatitis $C$ such patients may be candidatesfor liver transplantation.

RECOMMENDATION: In the absence of evidence of benefit from screening, the committee felt that no recommendation could be made for or against screening.

\section{HEPATITIS G}

Hepatitis $\mathrm{G}$ virus is structurally similar to HCV but shares only about $25 \%$ genetic homology (56). Little is known about the virus's ability to cause liver disease. It is clear that the virus can exist in blood and can be transmitted by transfusion. It may cause a transient elevation of the aminotransferases and may persist for months to years after transfusion. However, evidence that it can cause chronic liver disease is inconclusive. The virus has been detected in the serum of patients with cirrhosis, with no other apparent cause of liver disease identified. Recent data, however, suggest that hepatitis $\mathrm{G}$ does not cause chronic liver disease $(57,58)$. At present, assays for hepatitis $G$ are based on nucleic acid detection, and so are unsuitable for screening purposes. When 
newer antibody-based tests are available, screening may be more widely applied. However, based on current knowledge, the consensus group does not recommend widespread testing.

\section{ROLE OF THE PUBLIC HEALTH AUTHORITIES}

Public health authorities in Canada (where specific diseases are notifiable) have the responsibility of prevention and control, which may include tracing contacts of patients and, in the case of hepatitis $B$, arranging and ensuring vaccination. However, until recently only acute hepatitis B triggered follow-up in many jurisdictions, and only a few public health units undertook the same follow-up for chronic hepatitis $\mathrm{C}$. Furthermore, the information provided to patients by different public health units was often inadequate or even incorrect.

RECOMMENDATION: All public health authorities should adopt a standard approach to monitoring viral hepatitis. This approach should include full follow-up and contact tracing for both acute and chronic hepatitis $\mathrm{B}$ and C. All patients should be given full accurate and current information about their infection. This information should be standardized across all public health units. All public health units should collect data on acute and chronic hepatitis $B$ and $C$ in a standard manner.

Contact tracing is currently done mainly for acute hepatitis B. However, contact tracing should be done for chronic hepatitis B as well. All family and sexual contacts should be screened for the presence of hepatitis $B$. The objective of screening should be to identify subjects at risk for hepatitis B,

\section{REFERENCES}

1. The CASL Hepatit is Consensus Group. Treatment of chronic viral hepatitis with alpha-interferon: A consensus conference report. Can J Gastroenterol 1994;8:179-84.

2. Niederau C, Heintges T, Niederau M, Stremmel W, Strohmeyer G. Prospective randomized controlled trial of sequential treatment with corticoids and alpha-interferon versus treatment with interferon alone in patients with chronic active hepatitis B. Eur J Med 1992;1:396-402.

3. Reichen J, Bianchi L, Frei PC, Male PJ, Lavanchy D, Schmid M.

Efficacy of steroid withdrawal and low-dose interferon treatment in chronic active hepatitis B. Results of a randomized multicenter trial. Swiss Association for the Study of the Liver. J Hepatol $1994 ; 20: 168-74$.

4. Zarski JP, Causse X, Cohard M, Cougnard J, Trepo C. A randomized, controlled trial of interferon alpha- $2 \mathrm{~b}$ alone and with simultaneous prednisone for the treatment of chronic hepatitis B. French Multicenter Group. J Hepatol 1994;20:735-41.

5. Perrillo R, Tamburro C, Regenstein F, et al. Low-dose, titratable interferon alpha in decompensated liver disease caused by chron ic infection with hepatitis B virus. Gastroenterology 1995;109:908-16.

6. Lok AS, Hadziyann is SJ, Weller IV, et al. Contribution of low level HBV replication to continuing inflammatory activity in patients $w$ ith anti-HBe positive chronic hepatitis B virus infection. Gut $1984 ; 25: 1283-7$.

7. Fattovich G, McIntyre G, Thursz M, et al. Hepatitis B virus precore/core variation and interferon therapy. Hepatology $1995 ; 22: 1355-62$. to provide vaccination and to identify carriers. If subjects are screened with anti-HBc, the positive cases must also be tested for hepatitis $B$ surface antigen ( $\mathrm{HBs} A g$ ). It is not sufficient to identify those positive for hepatitis $B$ exposure and to vaccinate the rest. An alternate form of screening may be with $\mathrm{HBs} \mathrm{Ag}$ and anti-HBs. Those negative for both require vaccination.

Subjects who are HBsAg-positive must be referred to a physician for further evaluation. Those who have been exposed to hepatitis B must also be tested for chronic infection. All patients who are $\mathrm{HBsAg}$-positive should be provided with information about transmission of disease. All patients who are chronic carriers should be provided with similar information, as well as information about possible treatment.

Data should be collected on the number of notifications and the settings in which the infection was identified (symptomatic infection, asymptomatic carrier, contact tracing, etc).

The public health authorities should also collect data on hepatitis C. Contact tracing should be limited to injection drug use contacts. The Canadian Red Cross should be involved where possible to enable look-backs and trace-backs if the person may have been infected through the receipt of blood and blood products or if the person was a blood donor. Patients should be provided with appropriate information concerning their risk of chronic liver disease and the possibilities for treatment, and should be referred to a physician for assessment. Health units report notified cases of hepatitis $\mathrm{C}$ to the province or territory, which then pass the information to the Laboratory Centres for Disease Control.

ACKNOWLEDGEMENTS: The Consensus Conference was held under the auspices of the Canadian Association for Study of the Liver (CASL) and the Canadian Liver Foundation, and was supported by an unrestricted grant from the Canadian Liver Foundation.

8. Brunetto MR, Oliveri F, Colombatto P, Capalbo M, Barbara C, Bonino F. Treatment of chronic antiHBe-positive hepatitis $\mathrm{B}$ with interferon-alpha. J Hepatol 1995;22(Supp 1):42-4A.

9. Sokal EM, Wirth S, Goyers S, et al. Interferon alpha $2 \mathrm{~b}$ therapy in children with chronic hepatitis B. Gut 1993;34:S87-90.

10. Ruiz-Moreno M, Rua MI, Molina J, et al. Prospective randomized trial of interferon alpha in children with chronic hepatitis B. Hepatology $1991 ; 13: 1035.9$.

11. Conjeevaram HS, Hoofnagle JH, Austin HA, Park Y, Fried MW, Di Bisceglie AM. Long-term outcome of hepatitis B virus-related glomerulonephritis after therapy with interferon alpha. Gastroenterology 1995;109:540-6.

12. Lin CY. Treatment of hepatitis B virus-associated membranous nephropathy with recombinant alpha-interferon. Kidney Int $1995 ; 47: 225-30$.

13. Farci P, Mandas A, Coiana A, et al. Treatment of chronic hepatitis D with interferon alpha-2a. N Engl J Med 1994;330:88-94.

14. Wong DK, Yim C, Naylor CD, et al. Interferon alpha treatment of chronic hepatitis $\mathrm{B}$ : randomized trial in a predominantly homosexual male population. Gastroenterology. 1995;108:165-71.

15. Pontisso P, Ruvoletto MG, Fattovich G, et al. Clinical and virological profiles in patients with multiple hepatitis virus infections. Gastroenterology 1993;105:1529-33.

16. Dienstag JL, Perillo RP, Schiff ER, Bartholomew M, Vicary C, Rubin M. A preliminary trial of lamivudine for chronic hepatitis B infection. N Engl J Med 1995;333:1657-61. 
17. Trepo C, Jezek P, Atkinson GF, Boon RJ. Efficacy of famciclovir in chronic hepatitis B: results of a dose finding study. Hepatology $1996: 24: 188 \mathrm{~A}$.

18. Seeff LB, Beebe GW, Hoofnagle JH, et al. A serologic follow-up of the 1942 epidemic of post-vaccination hepatitis in the United States Army. N Engl J Med 1987:316:965-70.

19. Tassopoulos NC, Theodoropoulos G, Sjogren MH, Engle R, Purcell RH. Serological markers of hepatitis B virus and hepatitis D virus infections in Greek adults with primary hepatocellular carcinoma. Infection 1989:1:17-9.

20. Franks AL, Berg CJ, Kane MA, et al. Hepatitis B virus infection among children born in the United States to Southeast Asian refugees. N Engl J Med 1989;321:1301-5.

21. Viladomiu L, Genesca J, Esteban JI, et al. Interferon-alpha in acute posttransfusion hepatitis C: a randomized, controlled trial. Hepatology 1992;15:767-9.

22. Lampertico P, Rumi M, Romeo R, et al. A multicenter randomized controlled trial of recombinant interferon-alpha $2 \mathrm{~b}$ in patients with acute transfusion-associated hepatitis C. Hepatology 1994;19:19-22.

23. Hwang SJ, Lee SD, Chan CY, Lu RH, Lo KJ. A randomized controlled trial of recombinant interferon alpha- $2 \mathrm{~b}$ in the treatment of Chinese patients with acute post-transfusion hepatitis C. J Hepatol $1994 ; 21: 831-6$.

24. An integrated protocol to manage health care workers exposed to bloodborne pathogens. Can Commun Dis Rep 1997:23S2.

25. Ohto H, Terazawa S, Sasaki N, et al. Transmission of hepatitis $\mathrm{C}$ virus from mothers to infants. The Vertical Transmission of Hepatitis C Virus Collaborative Study Group. N Engl J Med $1994 ; 330: 744-50$.

26. Bortolotti F, Giacchino R, Vajro P, et al. Recombinant interferon-alpha therapy in children with chronic hepatitis $C$. Hepatology 1995;22:1623-7.

27. Iorio R, Pensati P, Porzio S, Fariello I, Guida S, Vegnente A. Lymphoblastoid interferon alpha treatment in chronic hepatitis C. Arch Dis Child 1996;74:152-6.

28. Serfaty L, Chazouilleres O, Pawlotsky JM, Andreani T, Pellet C, Poupon R. Interferon alpha therapy in patients with chronic hepatitis $\mathrm{C}$ and persistently normal aminotransferase activity. Gastroenterology 1996;110:291-5.

29. Gholson CF, Favrot D, Taylor B, Catinis G, Balart L. Chronic hepatitis $C$ virus infection and persistently normal aminotransferases: a preliminary report of alpha-interferon resistance. Hepatology 1996:24:105A

30. Yoshioka $\mathrm{K}$, Higashi $\mathrm{Y}$, Yamada $\mathrm{M}$, et al. Predictive factors in the response to interferon therapy in chronic hepatitis C. Liver $1995 ; 15: 57-62$

31. Laurent-Puig P, Dussaix E, Altman C, et al. Host and viral characteristics affecting the response to interferon therapy in chronic hepatitis C. Eur J Gastroenterol Hepatol 1995;7:335-40.

32. Suzuki T, Tanaka E, Matsumoto A, Urushihara A, Sodeyama T. Usefulness of simple assays for serum concentration of hepatitis $C$ virus RNA and HCV genotype in predicting the response to patients with chronic hepatitis $C$ to interferon alpha 2a therapy. J Med Virol $1995 ; 46: 162-8$

33. Hayashi J, Ohmiya M, Kishihara Y, et al. A statistical analysis of predictive factors of response to human lymphoblastoid interferon in patients with chronic hepatitis C. Am J Gastroenterol $1994 ; 89: 2151-6$.

34. Simmonds P, Holmes EC, Cha TA, et al. Classification of hepatitis C virus into six major genotypes and a series of subtypes by phytogenetic analysis of the NS.5 region. J Gen Virol 1993;74:2391-9.

35. Tsubota A, Chayama K, Ikeda K, et al. Factors predictive of response to interferon-alpha therapy in hepatitis $\mathrm{C}$ virus infection. Hepatology 1994:19:1088-94.

36. Martinot-Peignoux M, Marcellin P, Pouteau M, et al. Pretreatment serum hepatitis $C$ virus RNA levels and hepatitis $C$ virus genotype are the main and independent prognostic factors of sustained response to interferon alpha therapy in chronic hepatitis C. Hepatology $1995 ; 22: 1050-6$

37. Poynard T, Bedossa P, Chevallier M, et al. A comparison of three interferon alpha-2b regimens for the long-term treatment of chronic
non-A, non-B hepatitis. Multicenter Study Group. N Engl J Med $1995 ; 332: 1457.62$

38. Lin R, Roach E, Zimmerman M, Strasser S, Farrell GC. Interferon alpha $2 \mathrm{~b}$ for chronic hepatitis $\mathrm{C}$ : effects of dose increment and duration of treatment on response rates. Results of the first multicentre Australian trial. Australia Hepatitis C Study Group. J Hepatol 1995;23:487-96.

39. Reichard O, Foberg U, Fryden A, et al. High sustained response rate and clearance of viremia in chronic hepatitis $\mathrm{C}$ after treatment with interferon alpha $2 \mathrm{~b}$ for 60 weeks. Hepatology 1994;19:280-5.

40. Poynard T, Leroy V, Cohard M, et al. Meta-analysis of interferon randomized trials in the treatment of viral hepatitis C. Effects of dose and duration. Hepatology 1996:24:778-89.

41. Marcellin P, Pouteau M, Martinot-Peignoux M, et al. Lack of benefit of escalating dosage of interferon alpha in patients with chronic hepatitis C. Gastroenterology 1995;109:156-65.

42. Liou TC, Chang TT, Young KC, Lin XZ, Lin CY, Wu HL. Detection of HCV RNA in saliva, urine, seminal fluid, and ascites. J Med Virol 1992;37:197-202.

43. Couzigou P, Richard L, Dumas F, Schouler L, Fleury H. Detection of HCV-RNA in saliva of patients with chronic hepatitis C. Gut 1993;34(Suppl):S59-60

44. Kurauchi O, Furui T, Itakura A, et al. Studies on transmission of hepatitis $\mathrm{C}$ virus from mother-to-child in the perinatal period. Arch Gynecol Obstet 1993;253:121-6.

45. Fried MW, Shindo M, Fong TL, Fox PC, Hoofnagle JH, Di Bisceglie AM. Absence of hepatitis $C$ viral RNA from saliva and semen of patients with chronic hepatitis C. Gastroenterology 1992:102:1306-8.

46. Silverman AL, Puccio JE, Kulesza GW, McCray DG, Gordon SC. HCV RNA is present in the menstrual blood of women with chronic hepatitis C infection. Am J Gastroenterol 1984;89:1201-2.

47. Bresters D, Mauser-Bunschoten EP, Reesink HW, et al. Sexual transmission of hepatit is $C$ virus. Lancet 1993:342:210-1.

48. Stary A, Kopp W, Hofmann H, Heller-Vitouch C, Kunz C. Seroepidemiologic study of hepatitis $\mathrm{C}$ virus in sexually transmitted disease risk groups. Sex Transm Dis 1992;19:252-8.

49. Bodsworth NJ, Cunningham P, Kaldor J, Donovan B. Hepatitis C virus infection in a large cohort of homosexually active men: independent associations with HIV 1 infection and injecting drug use but not sexual behaviour. Genitourin Med 1996;72:118-22.

50. Akahane Y, Kojima M, Sugai Y, et al. Hepatitis C virus infection in spouses of patients with type $C$ chronic liver disease. Ann Inter Med $1994 ; 120: 748-52$.

51. Thomas DL, Cannon RO, Shapiro CN, Hook EW III, Alter MJ, Quinn TC. Hepatitis C, hepatitis B, and human immunodeficiency virus infections among non-intravenous drug-using patients attending clinics for sexually transmitted diseases. J Infect Dis 1994;169:990-5.

52. Thomas DL, Zenilman JM, Alter HJ, et al. Sexual transmission of hepatitis $C$ virus among patients attending sexually transmitted diseases clinics in Baltimore - an analysis of 309 sex partnerships. I Infect Dis 1995;171:768-75.

53. Osmond DH, Charlebois E, Sheppard HW, et al. Comparison of risk factors for hepatitis $\mathrm{C}$ and hepatitis B virus infection in homosexual men. J Infect Dis 1993;167:66-71.

54. Heyward WL, Lanier AP, McMahon BJ, Fitzgerald MA, Kilkenny S, Paprocki TR. Early detection of primary hepatocellular carcinoma. Screening for primary hepatocellular carcinoma among persons infected with hepatitis B virus. JAMA 1985;254:3052-4.

55. Sherman M, Peltekian KM, Lee C. Screening for hepatocellular carcinoma in chronic carriers of hepatit is B virus incidence and prevalence of hepatocellular carcinoma in a North American urban population. Hepatology 1995;22:432-8.

56. Linnen J, Wages J Jr, Zhang-Keck ZY, et al. Molecular cloning and disease association of hepatitis $\mathrm{G}$ virus: a transfusion-transmissible agent. Science 1996:271:505-8.

57. Alter MJ, Gallagher M, Morris T, et al. Acute non-A.E hepatitis in the United States and the role of hepatitis $\mathrm{G}$ infection. N Engl J Med 1997;336:741-6.

58. Alter HJ, Nakatsuji Y, Melpolder J, et al. The incidence of transfusion-associate hepatitis $G$ virus infection and its relation to liver disease. N Engl J Med 1997;333:747-54. 


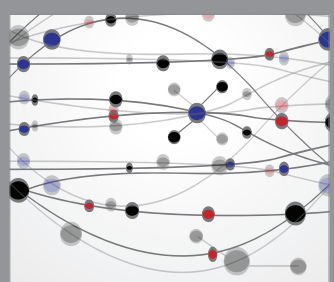

The Scientific World Journal
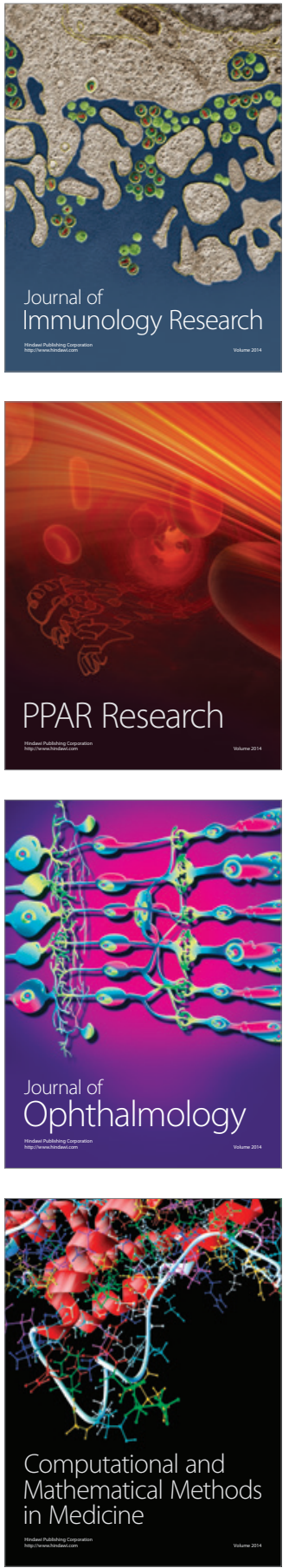

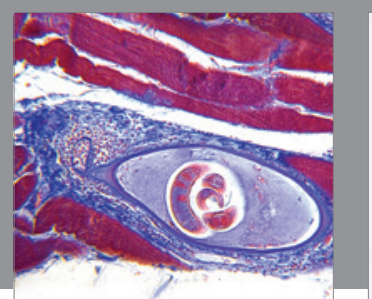

Gastroenterology Research and Practice

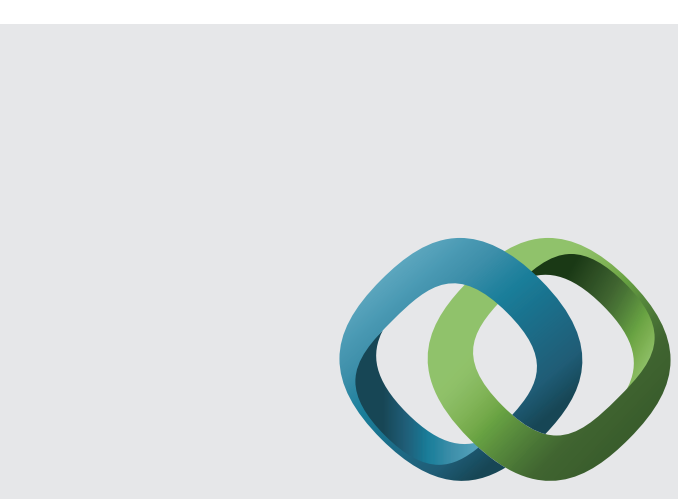

\section{Hindawi}

Submit your manuscripts at

http://www.hindawi.com
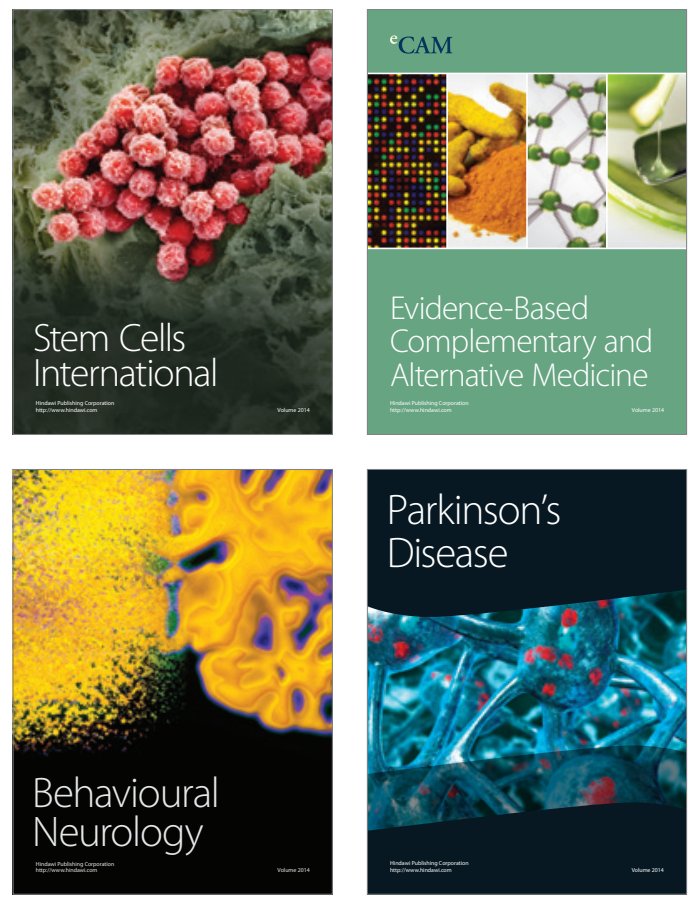
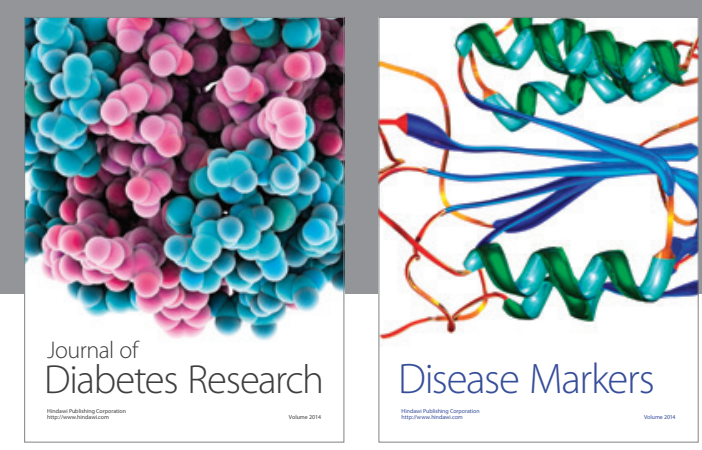

Disease Markers
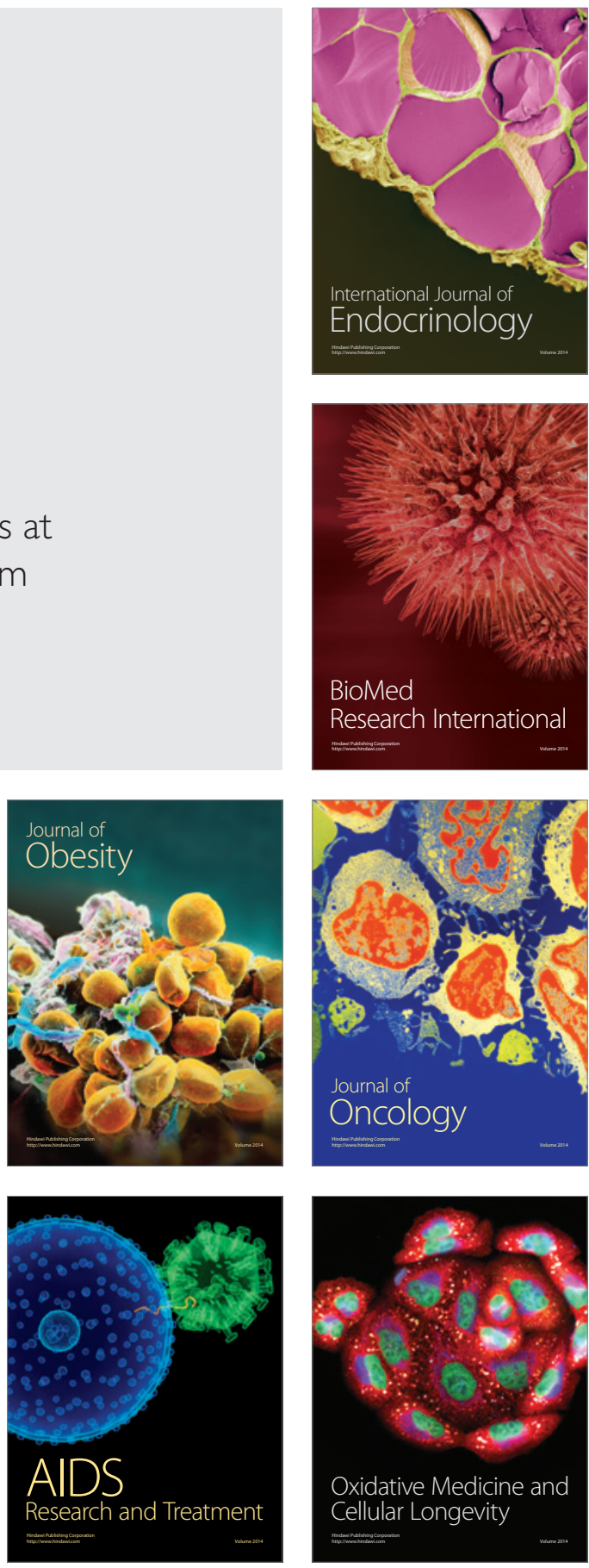